\title{
Clinical characteristics of 2019 novel coronavirus-infected pneumonia in China: A systematic review and meta-analysis of observational studies
}

\author{
Mingjin Yang ${ }^{1}$, Yan Zhang ${ }^{1}$, Yuejun $\mathrm{Du}^{1}$, and Depeng Jiang ${ }^{2}$ \\ ${ }^{1}$ Chengdu Second People's Hospital \\ ${ }^{2}$ Chongqing Medical University Affiliated Second Hospital
}

August 23, 2020

\begin{abstract}
Background: As of March 31, 2020, about 82,545 COVID-19-infected patients in China have been confirmed. Several observational studies have reported clinical characteristics of pneumonia caused by COVID-19 in China. But there are doubts about the clinical significance of differences reported in the different studies. The objective of this paper is to meta-analyze all available data from observational studies in China to enable an objective reappraisal of the clinical characteristics. Methods: PubMed, CNKI, EMBASE, and Cochrane Library were searched. Observational studies were included if they reported information on clinical characteristics of COVID-19-infected pneumonia. Statistical heterogeneity was assessed using the I2 test, with a value [?] $50 \%$ indicating a substantial level of heterogeneity. Results: Pooled results exhibited that the proportion of male (58\%) was higher in patients with COVID-19-infected pneumonia. Fever (89\%), cough (74\%), fatigue (44\%), and shortness of breath (31\%) were the common clinical manifestations. Cardiovascular disease (8\%), endocrine system disease (9\%), and digestive system disease (5\%) were the common comorbidities. Moreover, hypertension (29\%), endocrine system disease (16\%), and cardiovascular disease $(8 \%)$ were the most common comorbidities in severe patients. Acute cardiac injury (5\%), ARDS (11\%), shock (3\%), and AKI (2\%) were the common complications. Conclusions: Men may be more susceptible to COVID-19. The people with hypertension and endocrine system disease are more likely to develop severe pneumonia. The most common symptoms are fever and cough. The heart and kidneys may be also important organs for the COVID-19 to attack in addition to the lungs. Most patients have bilateral imaging abnormalities.
\end{abstract}

\section{Introduction}

In December 2019, several cases of novel coronavirus-infected pneumonia have been reported in Wuhan, a large city of 11 million people in China [1-3]. Then, the novel coronavirus was identified by the Chinese Center for Disease Control and Prevention from the throat swab and bronchoalveolar lavage fluid samples of patients in Wuhan, and was next named COVID-19 by WHO [4]. The disease spread rapidly from Wuhan to other parts of China. As of March 31, 2020, about 82,545 COVID-19-infected patients in China have been confirmed. More than 50 countries have reported confirmed cases worldwide. Most patients have mild symptoms and good prognosis, while a few develop severe pneumonia, acute respiratory distress syndrome (ARDS), multiple organ failure, or even death.

At present, several observational studies have offered information regarding the epidemiology and clinical features of pneumonia caused by COVID-19[5-13] Clinical manifestations of patients with COVID-19-infected pneumonia mainly include fever, headache, muscle ache, cough, dyspnea, fatigue, etc. A few patients developed ARDS, and multiple organ failure (eg. shock, acute cardiac injury, and acute kidney injury). However, data from different studies also showed significant differences in the incidence of fever, cough, dyspnea, etc. Huang et al found that the most common symptoms were fever (98.6\%), fatigue (69.6\%), and dry cough 
$(59.4 \%)$ at onset of illness [6]. Less common symptoms were dizziness, headache, abdominal pain, etc. Guan et al revealed that only a few patients had symptoms of fever (43.8\%) at onset of illness [10]. Accordingly, there are doubts about the clinical significance of differences reported in the different studies. We set out to meta-analyses of all available data from observational studies in China to enable an objective reappraisal of the clinical characteristics.

\section{Methods}

\section{Protocol and search strategy}

The study was conducted following the Preferred Reporting Items for Systematic review and MetaAnalysis[14]. Ethics committee approval is not applicable for this study. The search strategy was developed by experts in respiratory medicine. Search terms were as follows: ("COVID-19" or "novel coronavirusinfected pneumonia" or "NCIP" or "SARS-CoV-2" or "2019-nCoV") and ("Clinical characteristics" or "CT manifestations" or "symptom" or "epidemiological characteristics" or "clinical features") (e-Table 1). Two reviewers (Mingjin Y. and Yan Z.) independently searched PubMed, China National Knowledge Infrastructure (CNKI), EMBASE, and Cochrane Library from May 05, 2020 to May 27, 2020. Articles in Chinese or English were included.

\section{Study selection}

Studies were included if they met the following criteria: (1) original research, (2) patients with 2019 novel coronavirus-infected pneumonia, (3) reported incidences of clinical manifestations (including fever, headache, muscle ache, cough, dyspnea, fatigue, etc.) and/or complication (including ARDS, shock, acute cardiac injury, AKI, etc.), (4) Chinese or English. Disagreements pertaining to the inclusion of articles were resolved by discussion until a consensus was reached.

Two independent reviewers (Mingjin Y. and Yan Z.) extracted data in duplicate from included studies. The standard assessment tools were used for evaluation of the quality of included studies. Each included article was given a quality score (0 to 8$)$ based on fulfillment of the quality criteria[15].

\section{Statistical analysis}

The statistical analyses were performed using $\mathrm{R}$ version 2.14 [16-17]. The meta pack was used to calculate and generate the pooled estimates and forest plots. Publication bias was also investigated statistically using Egger and Begg tests [18-19]. Statistical heterogeneity was assessed using the $\mathrm{I}^{2}$ test, with a value [?] $50 \%$ indicating a substantial level of heterogeneity. Random effects models would be used when substantial statistical heterogeneity was present. A p-value [?] 0.05 was defined as statistically significant.

\section{RESULTS}

\section{Study selection and characteristics}

Our search strategy yielded a total of 2087 published studies. After further screening by reading the title, abstract, and/or full text, 9 studies met the inclusion criteria for further analysis. The 9 included studies enrolled 1,795 patients. The flowchart is shown in Fig.1. The 9 included studies were published from January 24, 2020 to February 22, 2020. Population sizes ranged from 29 to 1,099 patients. All patients were admitted to the hospital for treatment. Among the studies, eight were retrospective analysis and one was a descriptive study. Five reported clinical symptoms, complications, computed tomography (CT) images, and laboratory

findings. Seven reported clinical symptoms and CT images. One studies only provided the information of chronic medical illness, symptoms, and complications (Table 1).

Each included study was given a quality score (0 to 8$)$ based on fulfillment of the quality criteria. Of the included trials, one study was assessed as 7 (range 0-8). Seven studies were assessed as 5 . One was assessed as 4 (e-Table 2).

\section{Baseline characteristics}


All the included studies provided information about the gender of patients. The pooled results revealed that the proportion of male in patients was 0.58 (95\% CI 0.55, 0.60) $\left(\mathrm{I}^{2}=69 \%, \mathrm{p}<0.01\right)$ (Fig.2) (Table 2). Moreover, all the included studies also provided information about chronic respiratory diseases, hypertension, and endocrine system disease. The pooled results revealed that the proportion of patients with chronic respiratory diseases, hypertension, and endocrine system disease was 0.01 (95\% CI $0.01,0.02)\left(\mathrm{I}^{2}=0 \%, \mathrm{p}=0.91\right)$, $0.14(95 \%$ CI $0.07,0.24)\left(\mathrm{I}^{2}=94 \%, \mathrm{p}<0.01\right)$, and 0.09 (95\% CI $\left.0.07,0.10\right)\left(\mathrm{I}^{2}=45 \%, \mathrm{p}=0.02\right)$, respectively. Of the eligible trials, eight provided information about cardiovascular disease, malignant tumour, and digestive system disease. The pooled results revealed that the proportion of patients with cardiovascular disease was 0.08 (95\% CI $0.03,0.17)\left(\mathrm{I}^{2}=95 \%, \mathrm{p}<0.01\right)$, malignant tumour was $0.02(95 \%$ CI $0.01,0.04)\left(\mathrm{I}^{2}=52 \%\right.$, $\mathrm{p}=0.03)$, and digestive system disease was 0.05 (95\% CI 0.03, 0.09) $\left(\mathrm{I}^{2}=79 \%, \mathrm{p}<0.01\right)$. (Fig.3A,B,C,D,E, and F) (Table 2).

Of the eligible trials, 2 studies provided a detailed age profile of patients with severe pneumonia. Data from one of the studies revealed that $28.8 \%$ developed severe pneumonia in patients over the age of 65 , and only $13.9 \%$ developed severe pneumonia in patients under the age of 65[10]. Another study suggested that $69.0 \%$ developed severe pneumonia in patients over the age of 70 , and only $34.2 \%$ developed severe pneumonia in patients under the age of 70[13]. Thus, the above hinted that older patients are more likely to develop severe pneumonia. But the data cannot be pooled due to the lack of further detailed information. Further subgroup analysis revealed that the proportion of severe patients with chronic respiratory system disease was $0.04(95 \%$ CI $0.02,0.08)\left(\mathrm{I}^{2}=0.00 \%, \mathrm{p}=0.28\right)$, cardiovascular disease was $0.08(95 \%$ CI $0.04,0.15)\left(\mathrm{I}^{2}=43 \%, \mathrm{p}=0.06\right)$, malignant tumour was $0.03(95 \%$ CI $0.01,0.06)\left(\mathrm{I}^{2}=0.00 \%, \mathrm{p}=0.17\right)$, digestive system disease was $0.03(95 \%$ CI $0.00,0.19)\left(\mathrm{I}^{2}=76 \%, \mathrm{p}<0.01\right)$, endocrine system disease was $0.16(95 \%$ CI $0.11,0.21)\left(\mathrm{I}^{2}=0.00 \%, \mathrm{p}=0.66\right)$, and hypertension was $0.29(95 \%$ CI $0.20,0.39)\left(\mathrm{I}^{2}=52 \%, \mathrm{p}=0.04\right)$. The proportion of non-severe patients with chronic respiratory system disease was $0.01(95 \%$ CI $0.00,0.04)\left(\mathrm{I}^{2}=63 \%, \mathrm{p}=0.01\right)$, cardiovascular disease was $0.02(95 \%$ CI $0.01,0.03)\left(\mathrm{I}^{2}=0.00 \%, \mathrm{p}=0.27\right)$, malignant tumour was $0.01(95 \%$ CI $0.00,0.04)\left(\mathrm{I}^{2}=55 \%\right.$, $\mathrm{p}=0.02)$, digestive system disease was $0.05(95 \%$ CI $0.02,0.13)\left(\mathrm{I}^{2}=87 \%, \mathrm{p}<0.01\right)$, endocrine system disease was $0.06(95 \%$ CI $0.05,0.08)\left(\mathrm{I}^{2}=0.00 \%, \mathrm{p}=0.06\right)$, and hypertension was $0.17(95 \%$ CI $0.11,0.25)\left(\mathrm{I}^{2}=70 \%, \mathrm{p}\right.$ $<0.01$ ) (Table 3 ).

\section{Signs and symptoms}

Nine studies provided information on fever, cough, shortness of breath, diarrhea, and fatigue in patients. The pooled results revealed that the proportion of patients with fever was 0.89 (95\% CI $0.81,0.94))\left(\mathrm{I}^{2}=91 \%\right.$, $\mathrm{p}<0.01)$, cough was $0.74(95 \%$ CI $0.59,0.84)\left(\mathrm{I}^{2}=96 \%, \mathrm{p}<0.01\right)$, shortness of breath was $0.31(95 \%$ CI $0.17,0.51)\left(\mathrm{I}^{2}=97 \%, \mathrm{p}<0.01\right)$, diarrhoea was $0.08(95 \%$ CI $0.04,0.17)\left(\mathrm{I}^{2}=92 \%, \mathrm{p}<0.01\right)$, and fatigue was 0.44 (95\% CI 0.31,0.59) ( $\left.\mathrm{I}^{2}=95 \%, \mathrm{p}<0.01\right)$. Moreover, of the eligible trials, eight, seven, and four provided information about headache, muscle ache, and sore throat, respectively. The pooled results revealed that the proportion of patients with headache was $0.14(95 \%$ CI $0.09,0.22)\left(\mathrm{I}^{2}=90 \%, \mathrm{p}<0.01\right)$, muscle ache was $0.030(95 \%$ CI $0.20,0.42)\left(\mathrm{I}^{2}=92 \%, \mathrm{p}<0.01\right)$, and sore throat was $0.03(95 \%$ CI $0.00,0.19)\left(\mathrm{I}^{2}=98 \%, \mathrm{p}=0.12\right)$ (eFigure 1 in the Supplement).

\section{Complications and Chest CT Manifestations}

Five studies reported that a small number of patients developed shock. Estimates of the proportion of patients developing shock were $0.03(95 \%$ CI $0.01,0.07)\left(\mathrm{I}^{2}=81 \%, \mathrm{p}<0.01\right)$. Data from 6 studies that reported information on ARDS was pooled. The results revealed that the proportion of patients developed ARDS was $0.11(95 \%$ CI $0.05,0.22)\left(\mathrm{I}^{2}=92 \%, \mathrm{p}<0.01\right)$. There were five or three studies offering data of patients developing acute kidney injury (AKI) or acute cardiac injury, respectively. The pooled results showed that the proportions of patients developing AKI or acute cardiac injury were 0.02 (95\% CI 0.01, $0.04)\left(\mathrm{I}^{2}=55 \%, \mathrm{p}=0.04\right)$ or $0.05(95 \%$ CI $0.01,0.17)\left(\mathrm{I}^{2}=72 \%, \mathrm{p}=0.61\right)$, respectively (Fig.4A,B,C,and D).

Eight studies provided information on chest x-ray or CT findings. The pooled results revealed that the proportion of patients with bilateral pneumonia was 0.79 (95\% CI $0.69,0.87)\left(\mathrm{I}^{2}=92 \%, \mathrm{p}<0.01\right)$, unilateral pneumonia was 0.11 (95\% CI 0.04, 0.27) ( $\left.\mathrm{I}^{2}=97 \%, \mathrm{p}<0.01\right)$ (eFigure 2 in the Supplement). 


\section{DISCUSSION}

This systematic review and meta-analysis of observational studies in China used subgroups analyses to objectively reappraise the clinical characteristics of patients with COVID-19-infected pneumonia, including age, sex, chronic medical illness, symptoms, complications, chest radiogram, etc. To our knowledge, this is the first systematic review and meta-analysis of all available trials in China to explore the clinical characteristics of patients with COVID-19-infected pneumonia.

Previous studies have suggested that people of all ages are susceptible to the COVID-19, but older people or those with chronic medical illness are more likely to develop severe pneumonia, ARDS, multiple organ failure, or even death [20-22]. Congruent with previous descriptive reports, we also found that COVID-19-infected pneumonia is common in all age groups. Moreover, our results also revealed that people with cardiovascular disease or endocrine system disease have a higher risk of developing ARDS, multiple organ failure, or even death. However, there were insufficient data from those studies to perform a further meta-analysis. Sex may also contribute to differences in incidence of COVID-19-infected pneumonia. Several observational studies have reported that the incidence of COVID-19-infected pneumonia was higher in men [6-9]. Our results were also consistent with previous report. However, the sex dependence of COVID-19 infections is different from that of severe acute respiratory syndrome (SARS), which as one of the beta-coronavirus family was more than $82 \%$ identical to RNA sequence of COVID-19 [23-24]. But our results were limited by the sample size. Future research may shed more light on the issue. In addition, when data on symptoms, complications, and comorbidities were pooled, statistical heterogeneity was detected. The source of heterogeneity may be that the proportion of each type of symptoms, complications, and comorbidities varied widely among the included studies. Recent publications have reported that the clinical characteristics of COVID-19-infected pneumonia mimicked those of SARS [24]. The dominant symptoms include fever and cough. Fatigue and shortness of breath are also common symptoms, whereas gastrointestinal symptoms were rare. Our results were also consistent with previous report. Notably, Guan and colleagues reported that fever occurred in only $43.8 \%$ of patients at onset of illness and developed in $87.9 \%$ following hospitalization [10]. But Wang and colleagues reported that the most common symptoms at onset of illness were fever $(98.6 \%)[9]$. The above differences may confuse readers. In combination with our results, it is considered that fever may be the most common symptom in the course of pneumonia but not in the onset. Huang and colleagues reported that a few patients developed ARDS (29\%), acute cardiac injury (12\%), and acute kidney injury (7\%), and suggested that the heart and kidneys are also important organs for the COVID-19 to attack in addition to the lungs [6]. Consistent with previous studies, our results also exhibited that COVID-19-related heart and kidney injury were also common in severe patients. It seems to further suggest that the lungs may be just a channel for the COVID-19 to attack vital organs in severe patients. But the results also need to be further verified in future studies. In terms of laboratory tests, the included studies-suggested that lymphocyte absolute counts were decreased in most patients, while the white blood cell counts were not detected to be significantly abnormal. This result hinted that COVID-19 might also act on lymphocytes, especially T lymphocytes, as does SARSCoV [25-26]. However, impaired function of immune system may significantly increase the risk of secondary infection in patients with COVID-19-infected pneumonia. The above may also be the reason why a few patients progressed rapidly with severe bacterial infections, which was eventually followed by multiple organ failure. The included studies showed that abnormalities in chest CT images were detected among all patients on admission. The pooled results revealed that most patients (68\%) had bilateral pneumonia. The typical findings of chest imaging showed bilateral ground glass opacity and multiple lobular of consolidation. However, chest imaging of patients usually changes dynamically. In clinical work, we should observe dynamically chest imaging of patients according to their conditions. In addition, it should not be overlooked that some carriers of COVID-19 may have no any clinical symptoms or exhibit typical clinical symptoms but no abnormal changes in chest imaging [27-28]. Some limitations of this systematic review and meta-analysis should be taken into account. First, this paper was limited to 9 observational studies with 1,795 patients. This sample size was not large enough to provide decisional clinical evidence. Second, some observational studies with insufficient information were excluded, which might lead to selection bias. Third, due to incomplete laboratory results provided by included studies, it is not possible 
to further explore the relationship between biomarkers and COVID-19-infected pneumonia.

In summary, people of all ages are susceptible to COVID-19, but older people or those with chronic medical illness are more likely to develop severe pneumonia, ARDS, multiple organ failure, or even death. Moreover, the incidence of COVID-19-infected pneumonia may be higher in men. The dominant symptoms include fever and cough. Fatigue and shortness of breath are also common symptoms, whereas gastrointestinal symptoms were rare. The heart and kidneys may be also important organs for the COVID-19 to attack in addition to the lungs. Lymphocyte absolute counts in most patients were decreased, and that patients with secondary bacterial infections might appear elevated leucocytes. Most patients may have bilateral imaging abnormalities. The typical findings of chest imaging showed bilateral ground glass opacity and multiple lobular of consolidation.

\section{Acknowledgments}

The authors are indebted to all members of the Respiratory Diseases Laboratory of Chengdu Second People's Hospital. All authors contributed substantially to the study design, data analysis and interpretation, and the writing of the manuscript. Conceived and designed the experiments: Mingjin Yang, Depeng Jiang. Performed the experiments: Yan Zhang. Analyzed the data: Mingjin Yang, Zhibo Xu, Depeng Jiang. Contributed reagents/materials/analysis tools: Yuejun Du. Wrote thefirst draft of the manuscript: Zhang Yan, Mingjin Yang.

\section{Ethics approval and consent to participate}

As this is a meta-analysis, ethics committee approval is not applicable.

\section{Declaration of Interest}

The authors declare no conflicts of interest.

\section{Funding/Support}

None.

\section{References}

1. The 2019-nCoV Outbreak Joint Field Epidemiology Investigation Team, Li Q. Notes from the field: an outbreak of NCIP (2019-nCoV) infection in China Wu-han, Hubei Province, 2019-2020. China CDC Weekly 2020; 2: 79-80.

2. LuH,StrattonCW,TangYW.Outbreak of pneumonia of unknown etiologyin Wu han China:the mystery and the miracle [published January16,2020]. J Med Virol.2020.

3. Zhu N, Zhang D, Wang W, et al. A novel coronavirus from patients with pneumonia in China, 2019. N Engl J Med. 2020 January 24.

4. WHO Director-General's remarks at the media briefing on 2019-nCoV on 11 February 2020. Retrieved February 11, 2020, fromhttps://www.who.int/dg/speeches/detail/who-director-general-s-remarks-atthe-media-briefing-on-2019-ncov-on-11-february-2020.

5. Chen Lei, Liu Huiguo, Liu Wei, Liu Jing, Liu Kui, Shang Jin, Deng Yan, Wei Shuang. Analysis of clinical features of 29 patients with 2019 novel coronavirus pneumonia.Zhonghua Jie $\mathrm{He} \mathrm{He} \mathrm{Hu} \mathrm{Xi} \mathrm{Za}$ Zhi. 43 (0), E005.

6. Chaolin Huang, Yeming Wang, Xingwang Li, Lili Ren, Jianping Zhao, Yi Hu, Li Zhang, Guohui Fan, Jiuyang $\mathrm{Xu}$, et al.Clinical Features of Patients Infected With 2019 Novel Coronavirus in Wuhan, China.Lancet. 395 (10223), 497-506.

7. Lu Yunfei,Yang Zongguo,Wang mei,Shi jia,et al. Analysis on Chinese medical clinical characteristics of 50 patients with 2019-nCov-infected pneumonia. Academic Journal of Shanghai University of Traditional Chinese Medicine Vol.34 No.2 Mar.2020.

8. Nanshan Chen, Min Zhou, Xuan Dong, Jieming Qu, Fengyun Gong, Yang Han, Yang Qiu, Jingli Wang, Ying Liu, Yuan Wei, Jia'an Xia, Ting Yu, Xinxin Zhang, Li Zhang.Epidemiological and Clinical 
Characteristics of 99 Cases of 2019 Novel Coronavirus Pneumonia in Wuhan, China: A Descriptive Study.Lancet. 395 (10223), 507-513.

9. Dawei Wang, Bo Hu, Chang Hu, Fangfang Zhu, Xing Liu, Jing Zhang, Binbin Wang, Hui Xiang, Zhenshun Cheng, Yong Xiong, Yan Zhao, Yirong Li, Xinghuan Wang, Zhiyong Peng. Clinical Characteristics of 138 Hospitalized Patients With 2019 Novel Coronavirus-Infected Pneumonia in Wuhan, China.JAMA. 2020 Feb 7.

10. Wei-jie Guan, Zheng-yi Ni, Yu Hu, Wen-hua Liang,Chun-quan Ou, MSc., Jian-xing He. Clinical Characteristics of Coronavirus Disease 2019 in China. N Engl J Med. 2020 Feb 28.

11. Kui L, Fang YY, Deng Y, Liu W, Wang MF, Ma JP, Xiao W, Wang YN, Zhong MH, Li CH, Li GC, Liu HG.Clinical characteristics of novel coronavirus cases in tertiary hospitals in Hubei Province. Chin Med J (Engl). 2020 Feb 7.

12. Xu XW, Wu XX, Jiang XG, Xu KJ, Ying LJ, Ma CL, Li SB, Wang HY, Zhang S, Gao HN, Sheng JF, Cai HL, Qiu YQ, Li LJ.Clinical findings in a group of patients infected with the 2019 novel coronavirus (SARS-Cov-2) outside of Wuhan, China: retrospective case series.BMJ. 2020 Feb 19;368:m606.

13. Jin-Jin Zhang, Xiang Dong, Yi-Yuan Cao, Ya-Dong Yuan, Yi-Bin Yang, You-Qin Yan, Cezmi A Akdis, Ya-Dong Gao.Clinical Characteristics of 140 Patients Infected by SARS-CoV-2 in Wuhan, China.Allergy. 2020 Feb 19.

14. Moher D, Liberati A, Tetzlaff J, Altman DG, Group P. Preferred reporting items for systematic reviews and meta-analyses: the PRISMA statement. BMJ. 2009;339:b2535.

15. Loney PL, Chambers LW, Bennett KJ, Roberts JG, Strafford PW. Critical appraisal of health literature:prevalence or incidence of a health problem. Chronic Dis Can. 1998;19:170-176.

16. R: A Language and Environment for Statistical Computing [Computer Program]. Vienna: R Foundation for Statistical Computing; 2011.

17. Schwarzer G. Meta: an R package for meta-analysis. R News. 2007;7:40-45.

18. Begg C, Mazumdar M. Operating characteristics of a rank correlation test for publication bias. Biometrics. 1994;50:1088-1101.

19. Egger M, Smith G. Bias in meta-analysis detected by simple, graphical test. Br Med J. 1997;315:629634.

20. Sukhyun Ryu, Byung Chul Chun.An Interim Review of the Epidemiological Characteristics of 2019 Novel Coronavirus.Epidemiol Health. 42, e2020006.

21. Zhangkai J Cheng, Jing Shan.2019 Novel Coronavirus: Where We Are and What We Know.Infection. 2020 Feb 18.

22. Qun Li, Xuhua Guan, Peng Wu, Xiaoye Wang, Lei Zhou, Yeqing Tong, Ruiqi Ren, Kathy S M Leung,etc. Early Transmission Dynamics in Wuhan, China, of Novel Coronavirus-Infected Pneumonia.N Engl J Med. 2020 Jan 29.

23. Yudong Yin, Richard G Wunderink. MERS, SARS and Other Coronaviruses as Causes of Pneumonia.Respirology. 23 (2), 130-137.

24. Lei Zhang, Yunhui Liu.Potential Interventions for Novel Coronavirus in China: A Systematic Review.J Med Virol. 2020 Feb 13.

25. Zumla A, Hui DS, Perlman S. Middle East respiratory syndrome. Lancet. 2015;386:995-1007.

26. Leung WK, To KF, Chan PK, et al. Enteric involvement of severe acute respiratory syndromeassociated coronavirus infection. Gastroenterology. 2003;125:1011-7.

27. Chen Chen, Dong Yanbing, Kang Jian, Lou Shuang, Wan Fen, Liu Hongmei, Zhang Jinsong. Asymptomatic novel coronavirus pneumonia presenting as acute cerebral infarction: case report and review of the literature. Chin J Emerg Med.2020,29: Epub ahead of print.

28. Wang Kai, Kang Si-ru, Tian Rong hua, Wang Yan, Zhang Xiao zhou, Li Hong-mei. CT characteristic appearances of patients with novel coronavirus pneumonia. Chinese Journal of Clinical Medicine, 2020, Vol. 27, No.1.

Table 1. The characteristics of the literature. 


\begin{tabular}{|c|c|c|c|c|c|c|c|}
\hline Authors & $\begin{array}{l}\text { No. of } \\
\text { Patients }\end{array}$ & Male(\%) & $\begin{array}{l}\text { Mean Age } \\
\text { (SD), y }\end{array}$ & Region & $\begin{array}{l}\text { Research } \\
\text { Type }\end{array}$ & $\begin{array}{l}\text { Clinical } \\
\text { Character- } \\
\text { istics }\end{array}$ & $\begin{array}{l}\text { Clinical } \\
\text { Character- } \\
\text { istics }\end{array}$ \\
\hline $\begin{array}{l}\text { Wang et } \\
\text { al(2020) }\end{array}$ & 138 & 54 & $56(19)$ & China & Retrospective & Strueltyospective S & $\begin{array}{l}\text { tubllyonic } \\
\text { medical } \\
\text { illness Signs } \\
\text { and } \\
\text { symptoms } \\
\text { laboratory } \\
\text { findings } \\
\text { Complica- } \\
\text { tions Chest } \\
\text { x-ray and } \\
\text { CT findings }\end{array}$ \\
\hline $\begin{array}{l}\text { Huang et } \\
\text { al(2020) }\end{array}$ & 41 & 73 & $49(13)$ & China & $\begin{array}{l}\text { Retrospective } \\
\text { Study }\end{array}$ & $\begin{array}{l}\text { Retrospective } \\
\text { Study }\end{array}$ & $\begin{array}{l}\text { Chronic } \\
\text { medical } \\
\text { illness Signs } \\
\text { and } \\
\text { symptoms } \\
\text { laboratory } \\
\text { findings } \\
\text { Complica- } \\
\text { tions Chest } \\
\text { x-ray and } \\
\text { CT findings }\end{array}$ \\
\hline $\begin{array}{l}\text { Liu et } \\
\text { al }(2020)\end{array}$ & 137 & 45 & $55(16)$ & China & $\begin{array}{l}\text { Retrospective } \\
\text { Study }\end{array}$ & $\begin{array}{l}\text { Retrospective } \\
\text { Study }\end{array}$ & $\begin{array}{l}\text { Chronic } \\
\text { medical } \\
\text { illness Signs } \\
\text { and } \\
\text { symptoms } \\
\text { Chest x-ray } \\
\text { and CT } \\
\text { findings }\end{array}$ \\
\hline $\begin{array}{l}\mathrm{Lu} \text { et } \\
\mathrm{al}(2020)\end{array}$ & 50 & 56 & $50(17)$ & China & $\begin{array}{l}\text { Retrospective } \\
\text { Study }\end{array}$ & $\begin{array}{l}\text { Retrospective } \\
\text { Study }\end{array}$ & $\begin{array}{l}\text { Chronic } \\
\text { medical } \\
\text { illness Signs } \\
\text { and } \\
\text { symptoms } \\
\text { Chest x-ray } \\
\text { and CT } \\
\text { findings }\end{array}$ \\
\hline $\begin{array}{l}\text { Zhang et } \\
\text { al(2020) }\end{array}$ & 140 & 51 & 57 & China & $\begin{array}{l}\text { Retrospective } \\
\text { Study }\end{array}$ & $\begin{array}{l}\text { Retrospective } \\
\text { Study }\end{array}$ & $\begin{array}{l}\text { Chronic } \\
\text { medical } \\
\text { illness Signs } \\
\text { and } \\
\text { symptoms } \\
\text { Chest x-ray } \\
\text { and CT } \\
\text { findings }\end{array}$ \\
\hline
\end{tabular}




\begin{tabular}{|c|c|c|c|c|c|c|c|}
\hline Authors & $\begin{array}{l}\text { No. of } \\
\text { Patients }\end{array}$ & Male(\%) & $\begin{array}{l}\text { Mean Age } \\
\text { (SD), y }\end{array}$ & Region & $\begin{array}{l}\text { Research } \\
\text { Type }\end{array}$ & $\begin{array}{l}\text { Clinical } \\
\text { Character- } \\
\text { istics }\end{array}$ & $\begin{array}{l}\text { Clinical } \\
\text { Character- } \\
\text { istics }\end{array}$ \\
\hline $\begin{array}{l}\text { Chen et } \\
\text { al }(2020)\end{array}$ & 99 & 68 & $55.5(13)$ & China & $\begin{array}{l}\text { Retrospective } \\
\text { Study }\end{array}$ & $\begin{array}{l}\text { Retrospective } \\
\text { Study }\end{array}$ & $\begin{array}{l}\text { Chronic } \\
\text { medical } \\
\text { illness Signs } \\
\text { and } \\
\text { symptoms } \\
\text { laboratory } \\
\text { findings } \\
\text { Complica- } \\
\text { tions Chest } \\
\text { x-ray and } \\
\text { CT findings }\end{array}$ \\
\hline $\begin{array}{l}\text { Guan et } \\
\text { al }(2020)\end{array}$ & 1099 & 58 & $47(17)$ & China & $\begin{array}{l}\text { Retrospective } \\
\text { Study }\end{array}$ & $\begin{array}{l}\text { Retrospective } \\
\text { Study }\end{array}$ & $\begin{array}{l}\text { Chronic } \\
\text { medical } \\
\text { illness Signs } \\
\text { and } \\
\text { symptoms } \\
\text { laboratory } \\
\text { findings } \\
\text { Complica- } \\
\text { tions Chest } \\
\text { x-ray and } \\
\text { CT findings }\end{array}$ \\
\hline $\begin{array}{l}\text { Chen Lei et } \\
\text { al(2020) }\end{array}$ & 29 & 72 & 56 & China & $\begin{array}{l}\text { Retrospective } \\
\text { Study }\end{array}$ & $\begin{array}{l}\text { Retrospective } \\
\text { Study }\end{array}$ & $\begin{array}{l}\text { Chronic } \\
\text { medical } \\
\text { illness Signs } \\
\text { and } \\
\text { symptoms } \\
\text { Complications }\end{array}$ \\
\hline $\begin{array}{l}\text { Xu et } \\
\text { al(2020) }\end{array}$ & 62 & 58 & $41(15)$ & China & $\begin{array}{l}\text { Retrospective } \\
\text { Study }\end{array}$ & $\begin{array}{l}\text { Retrospective } \\
\text { Study }\end{array}$ & $\begin{array}{l}\text { Chronic } \\
\text { medical } \\
\text { illness Signs } \\
\text { and } \\
\text { symptoms } \\
\text { Complica- } \\
\text { tions Chest } \\
\text { x-ray and } \\
\text { CT findings }\end{array}$ \\
\hline
\end{tabular}

SD, standard deviation. y,years.

Table 2. Pooled estimates for each type of baseline characteristics of patients infected with COVID-19.

\begin{tabular}{ll}
\hline Variable & $\begin{array}{l}\text { Included in the Meta-analysis }(\mathbf{n}=\mathbf{9}) \\
\text { Estimate }(\mathbf{9 5 \%} \mathbf{C I})\end{array}$ \\
\hline $\begin{array}{l}\text { Age,y } \\
\text { Sex }(\%)\end{array}$ & $47.91(47.70,48.12)$ \\
Male & $0.58(0.52,0.63)$
\end{tabular}




\begin{tabular}{ll}
\hline Variable & $\begin{array}{l}\text { Included in the Meta-analysis } \mathbf{( n = 9 )} \\
\text { Estimate }(\mathbf{9 5 \%} \mathbf{C I})\end{array}$ \\
\hline Female & $0.42(0.40,0.45)$ \\
Chronic medical illness (\%) & \\
Respiratory system disease & $0.01(0.01,0.02)$ \\
Cardiovascular disease & $0.08(0.03,0.17)$ \\
Malignant tumour & $0.02(0.01,0.04)$ \\
Digestive system disease & $0.05(0.03,0.09)$ \\
Endocrine system disease & $0.09(0.07,0.10)$ \\
Hypertension & $0.14(0.07,0.24)$ \\
Signs and symptoms (\%) & \\
Fever & $0.89(0.81,0.94)$ \\
Cough & $0.74(0.59,0.84)$ \\
Fatigue & $0.44(0.31,0.59)$ \\
Shortness of breath & $0.31(0.17,0.51)$ \\
Headache & $0.14(0.09,0.22)$ \\
Diarrhoea & $0.08(0.04,0.17)$ \\
Muscle ache & $0.30(0.20,0.42)$ \\
Sore throat & $0.03(0.00,0.19)$ \\
Complications (\%) & \\
Shock & $0.03(0.01,0.07)$ \\
ARDS & $0.11(0.05,0.22)$ \\
AKI & $0.02(0.01,0.04)$ \\
Acute cardiac injury & $0.05(0.01,0.17)$ \\
Chest x-ray and CT findings (\%) & \\
Bilateral pneumonia & $0.79(0.69,0.87)$ \\
Unilateral pneumonia & $0.11(0.04,0.27)$ \\
\hline & \\
\hline
\end{tabular}

Abbreviations: CI, confidence interval; CT, computed tomography; y, years; ARDS, acute respiratory distress syndrome; AKI, acute kidney injury.

Table 3. Pooled estimates for each type of chronic medical illness of proportion in non-severe or severe patients with COVID-19-infected pneumonia.

\begin{tabular}{lll}
\hline Chronic medical illness, (\%) & Included in the Meta-analysis Estimate (95\% CI) & Included in the Meta-ana \\
\hline & Non-severe & severe \\
Respiratory system disease & $0.01(0.00,0.04)$ & $0.04(0.02,0.08)$ \\
Cardiovascular disease & $0.02(0.01,0.03)$ & $0.08(0.04,0.15)$ \\
Malignant tumour & $0.01(0.00,0.04)$ & $0.03(0.01,0.06)$ \\
Digestive system disease & $0.05(0.02,0.13)$ & $0.03(0.00,0.19)$ \\
Endocrine system disease & $0.06(0.05,0.08)$ & $0.16(0.11,0.21)$ \\
Hypertension & $0.17(0.011,0.25)$ & $0.29(0.20,0.39)$ \\
Overall & $0.04(0.02,0.08)$ & $0.08(0.04,0.14)$ \\
\hline
\end{tabular}

Abbreviations: CI, confidence interval;

Figure 1 Flow of study selection 
Figure 1 PRISMA Flow Diagram
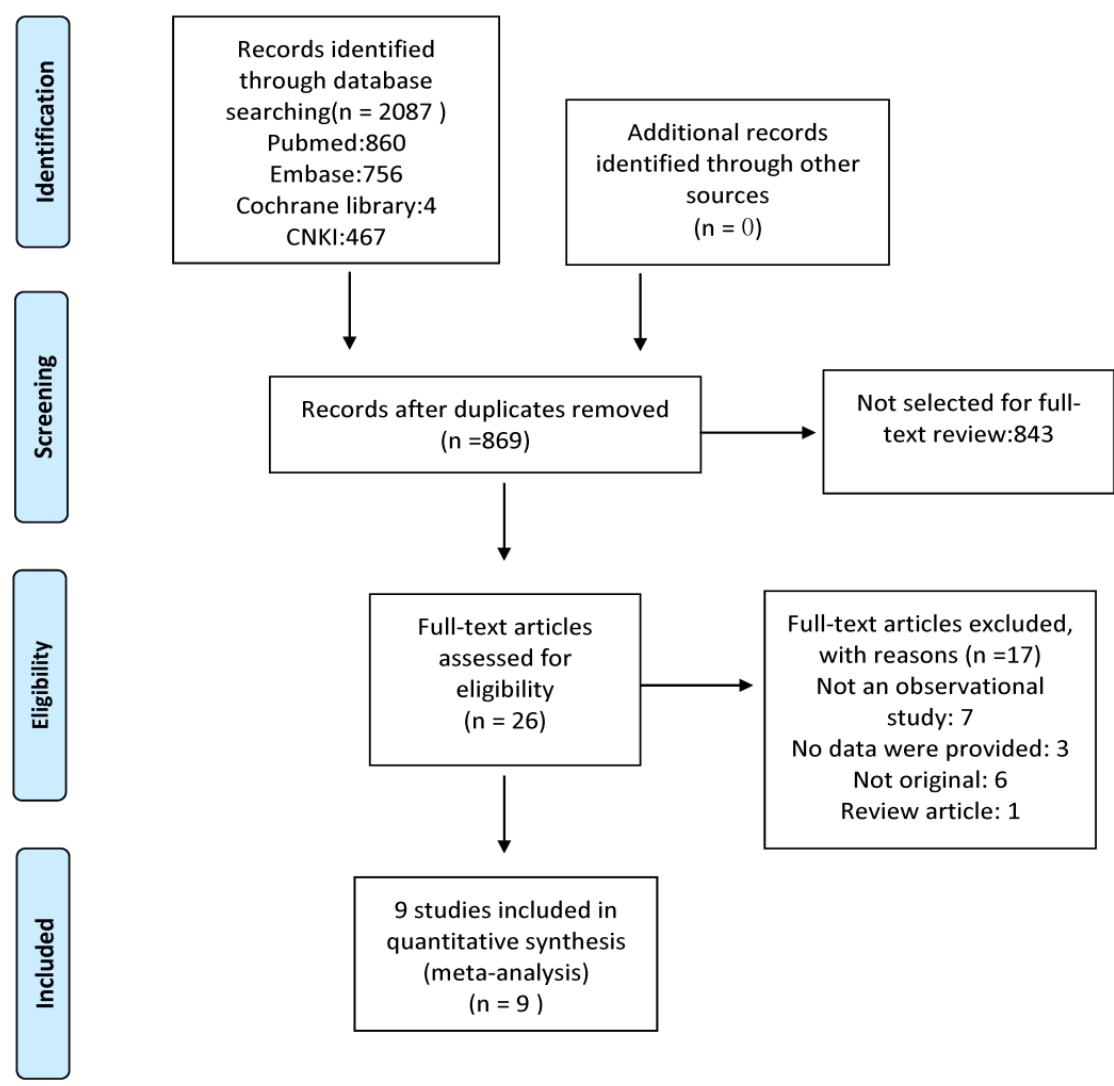

Full-text articles excluded, with reasons $(n=17)$ Not an observational study: 7

No data were provided: 3 Not original: 6 Review article: 1

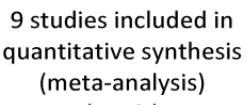

9 studies included in quantitative synthesis (meta-analysis) ( $n=9$ )

Chen et al2020

Chen Lei et a2020

Guan et al2020

Huang et al 2020

Live a2020

Luet al2020

Wang et ak020

Xuetal2020

Zhang et a/2020

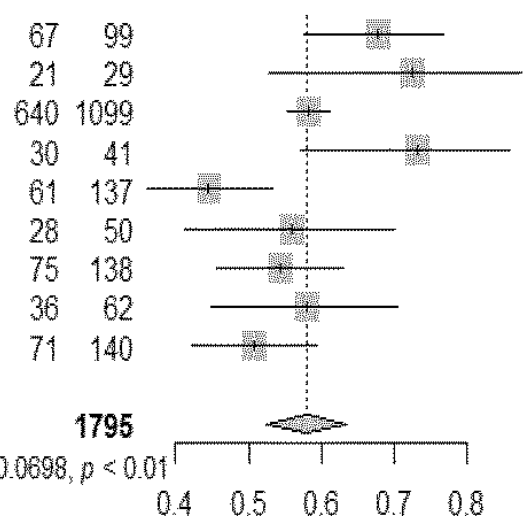

$0.68 \quad 0.58 ; 0.77]$

$0.72 \quad 0.53 ; 0.87]$

$0.58 \quad[0.55 ; 0.61]$

$0.73 \quad 0.57 ; 0.86$

$0.45 \quad 0.36,0.53]$

$0.56 \quad 0.41 ; 0.70]$

$0.54 \quad 0.46 ; 0.63$

$0.58 \quad 10.45 ; 0.70]$

$0.51 \quad[0.42 ; 0.59]$

$0.58[0.52 ; 0.63]$

Random effects model 
Figure 2 Pooled estimates for male or female of proportion in patients with COVID-19-infected pneumonia. CI, confidence interval.

Figure 3A,B,C,D,E, and F Pooled estimates for each type of comorbidity of proportion in patients with COVID-19-infected pneumonia.

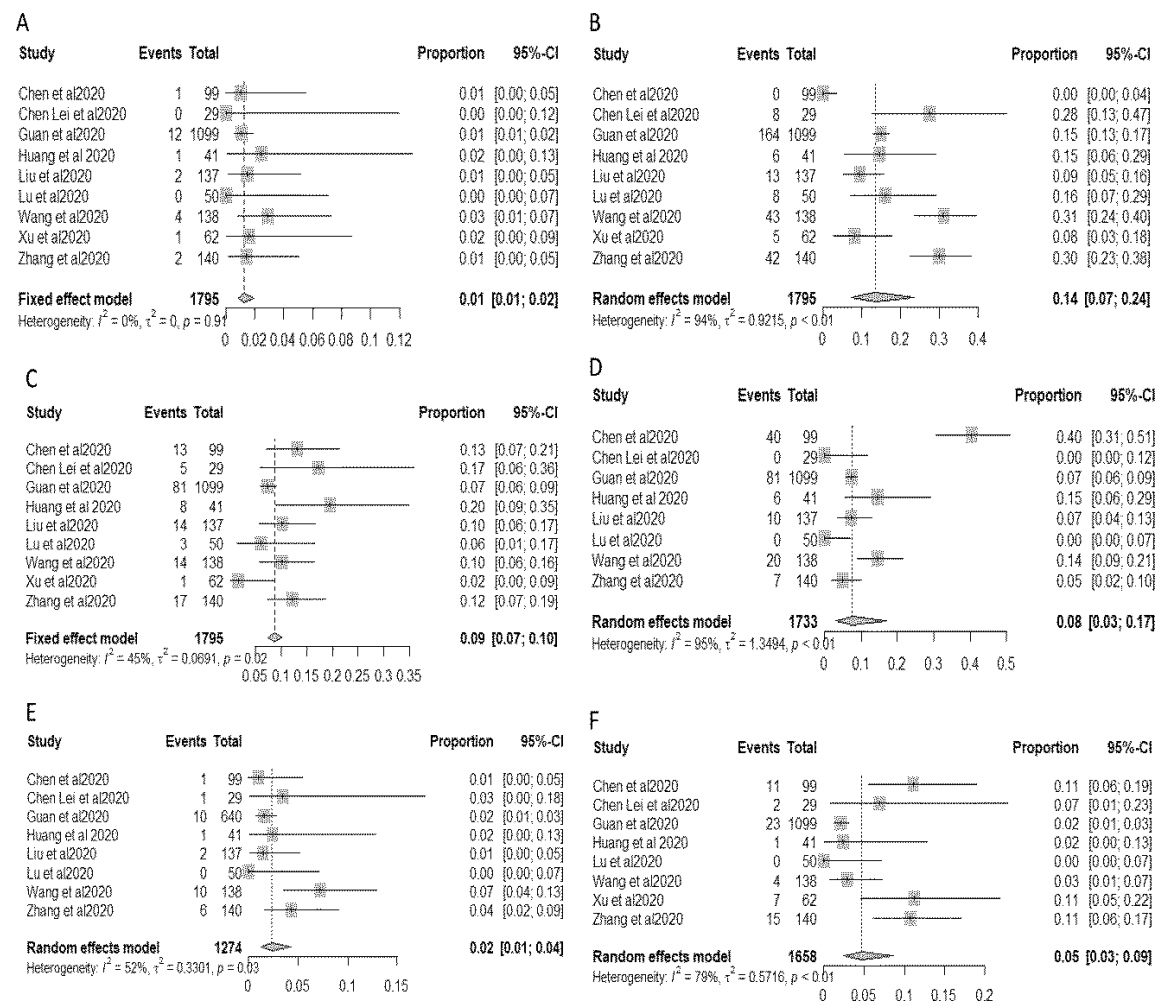

CI, confidence interval. A, chronic respiratory diseases; B, hypertension; C, endocrine system disease; D, cardiovascular disease; E, malignant tumour; and F, digestive system disease.

Figure 4A,B,C,and D Pooled estimates for each type of complication of proportion in patients with COVID-19-infected pneumonia. 


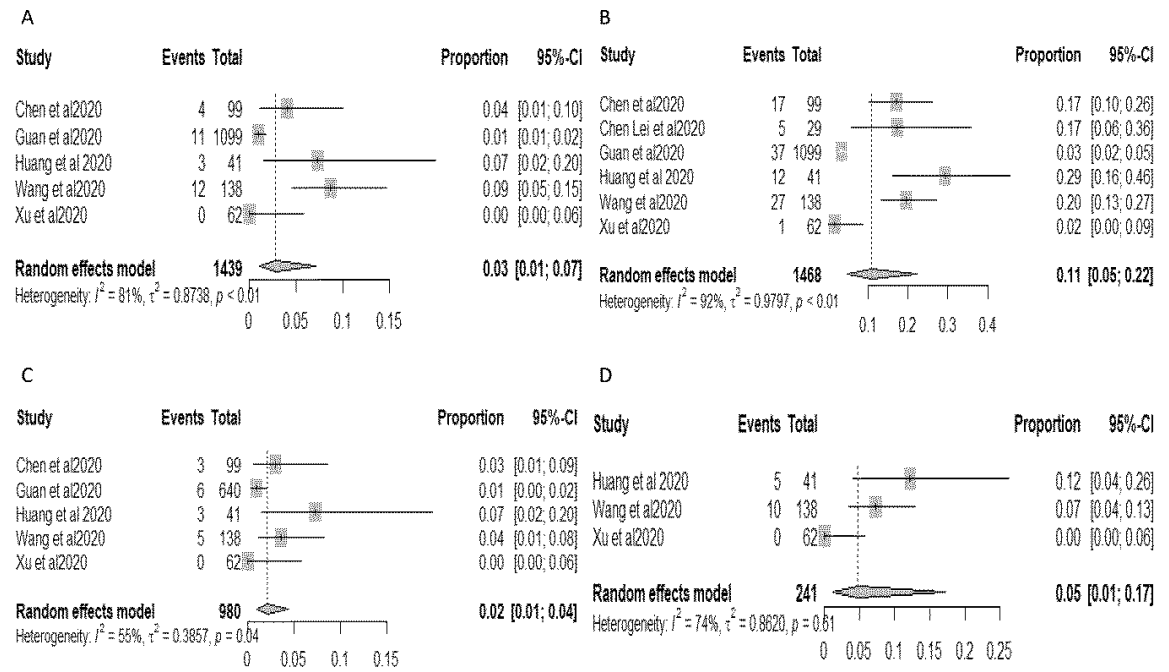

CI, confidence interval. A, shock; B, ARDS; C, AKI, and D, acute cardiac injury. 
Figure 1 PRISMA Flow Diagram
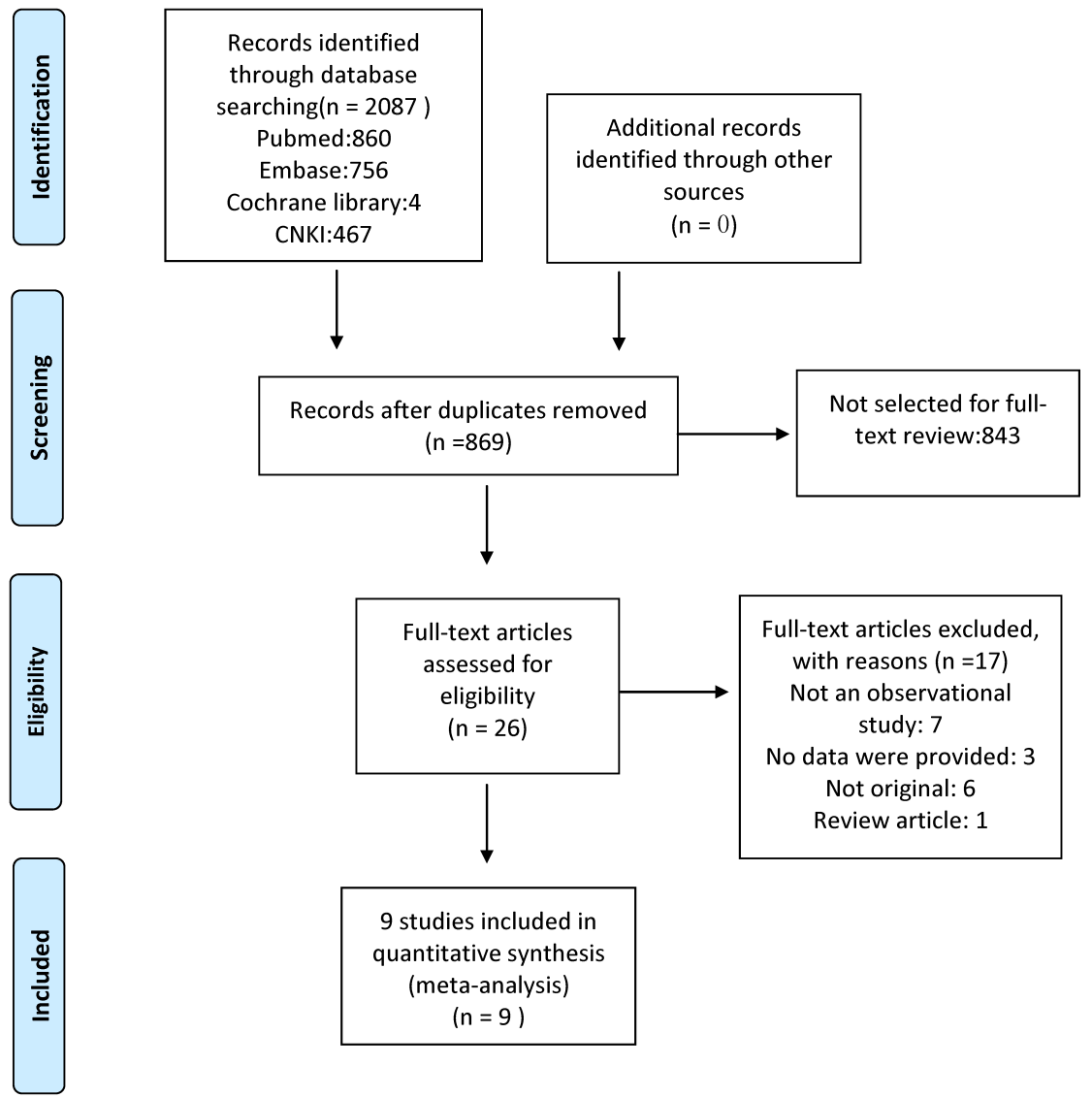

\begin{abstract}
9 studies included in quantitative synthesis (meta-analysis)
\end{abstract} $(n=9)$

Doi:10.1371/journal.pmed1000097. For more information, visit www.prisma-statement.org.

Study

Chen et al2020

Chen Lei et al2020

Guan et al 2020

Huang et al 2020

Liu et al2020

Lu et al2020

Wang et al2020

Xu et al2020

Zhang et al2020

\section{Events Total}

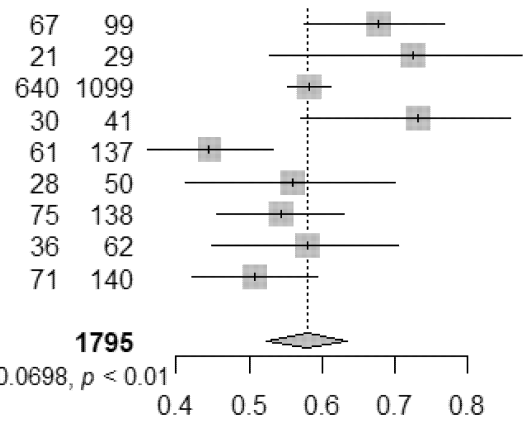

$\begin{array}{lllll}0.4 & 0.5 & 0.6 & 0.7 & 0.8\end{array}$

Proportion $\quad 95 \%-\mathrm{Cl}$

$0.68[0.58 ; 0.77]$

$0.72[0.53 ; 0.87]$

$0.58[0.55 ; 0.61]$

$0.73[0.57 ; 0.86]$

$0.45[0.36 ; 0.53]$

$0.56[0.41 ; 0.70]$

$0.54[0.46 ; 0.63]$

$0.58[0.45 ; 0.70]$

$0.51[0.42 ; 0.59]$

$0.58[0.52 ; 0.63]$

Random effects mode

Heterogeneity: $I^{2}=69 \%, \tau^{2}=0.0698, p<0.01$ 


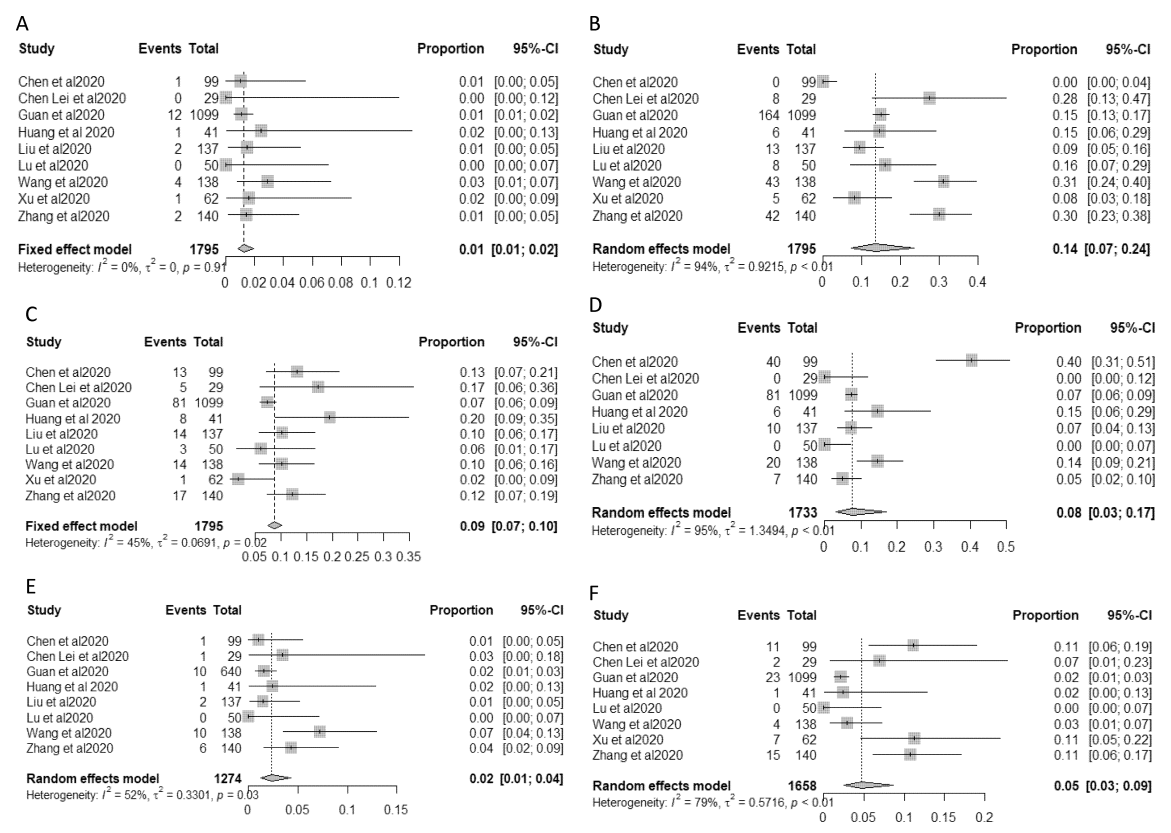

A

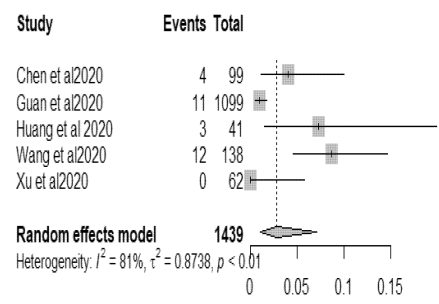

Proportion $95 \%$ Cl study

$0.04[0.01 ; 0.10]$ Chenetal2020

$0.01[0.01 ; 0.02]$ Chen Leie ta2020

0.07 [0.02:0.20] Guanetal2020

0.09 [0.05:0.15] Huang eta 2020

$0.00[0.00 ; 0.06]$ Wangetal2020

Events Total

Proportion $95 \%$.Cl

$0.03[0.01 ; 0.07]$ Random effects model Heterogeneity. $I^{2}=92 \%, \tau^{2}=0.9797, p<0.01$

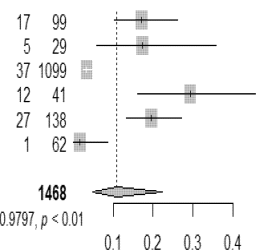

$0.17[0.10,0.26]$ $0.17[0.06,0.36]$ $0.03[0.02 ; 0.05]$ $0.29[0.16 ; 0.46]$ $0.20[0.13,0.27$

$0.11[0.05 ; 0.22]$

C

D

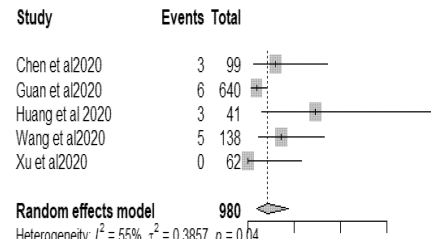

Heterogeneity. $I^{2}=55 \%, \tau^{2}=0.3857, p=0.04$

Proportion $95 \%$.Cl Study

Events Total

Proportion $95 \% \cdot C l$

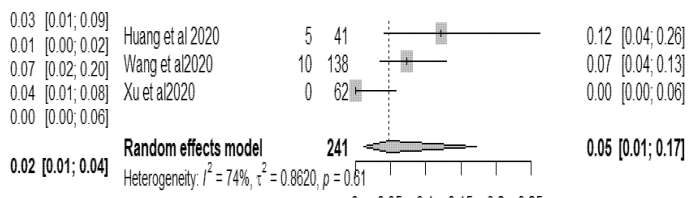

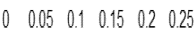

